\title{
Economic Crisis and Health Care Delivery System: a Study of Private Health Care Delivery in Port Harcourt, Nigeria
}

\author{
Bentina Alawari Mathias ${ }^{a *}$ and Athanasius N. Amasiatu ${ }^{b}$ \\ ${ }^{a}$ Nnamdi Azikiwe University \\ Awka, Nigeria \\ ${ }^{b}$ University of Port Harcourt \\ Choba, Nigeria
}

Received 20.01.2015, received in revised form 14.03.2015, accepted 21.04.2015

This paper examines the current economic crisis in Nigeria and its impact on private medical business using Port Harcourt City as a case study. It took a brief look at the Nigerian economic crisis as well as the relationship between the economic crisis and health care delivery system. A brief survey of the economic activities of the study area is made so as to adequately situate the study and facilitate the understanding of the social, economic and political conditions that have given so much prominence to private practices in Port Harcourt. It also attempts to trace the origin of private health care delivery system in Nigeria in general and Port Harcourt in particular as well as discuss the impact it had made. Finally, it gave some suggestions on how to improve the health care delivery system.

Keywords: economic crisis, health care, medical business, private practices.

Research area: economics.

\section{Introduction}

The economic condition of any society is determined by the society's increasing ability to master its environment and subsequently its ability to effectively combine the human and natural resources for efficient production when this is effectively done, it is usually said that the economy of the society is stable. This is usually reflected in the standard of living of the people.

A crisis situation sets in when the human and natural resources are not effectively combined or when the proceeds from the combination are controlled by only a few. This situation is made manifest in the society through unemployment, underemployment, hunger, poverty, diseases, poor housing, and rural-urban migration, poor medical services, low standard of education, bad roads, poor water supply, increasing number of destitute on the streets, scarcity of essential goods such as drugs and medicament, poor sanitation, social apathy, lack of the will and initiative to make changes for better and such likes (Igwe 1992, Tamuno 1998). In order to survive this crisis situation, the society devices mean of coping with it. In the health sector, which is the focus of this paper, economic crisis

(C) Siberian Federal University. All rights reserved

* Corresponding author E-mail address: mathiasbentina@gmail.com, bentinad1@yahoo.com 
affects both the profession as well as the society. The escalating economic crisis has constituted a major problem to all the regimes since 1979. Nigeria's recent governments (Shagari, 1979-1985, Babangida 1985-1993, Abacha 1993-1998, Abubakar 1998-1999, Obasanjo 1999-2008, Ya'adua 2008-2010 and Jonathan 2010-date), have responded to the escalating crisis by imposing austerity programmes prescribed directly by clubs of finance capital or through the agency of the IMF and the World Bank, enunciated in recent policy document as Structural Adjustment Programme (SAP) which was formally launched in 1986 and phased out as Babangida's administration ended. These polices had lead to a massive devaluation of the Naira, trade liberalization, commercialization of welfare services, privatization of public cooperation wages retrain measures and removal of subsidy (Alubo 1996, Olukoshi, 1991).

These austerity measures have exacerbated existing health problems. The incidence of nutritional disorders have reached a crisis proportion while epidemic of various communicable diseases including yellow fever thought to have been eradicated during the oil boom have become frequent (Osunkoyo, 1984). On the other hand, Nigeria elites have generally sought political powers as means of advancing their economic interests. They used power to gain access to share of profitable opportunities and the financial necessary to establish them as bourgeoisie. This is the main problem the country is facing. The proceeds from its natural and human resources are being appropriated by a few (Achebe 1983). In actual sense, every citizen of any country should have access to relatively quantitative and qualitative health care at all times as a constitutional right regardless of whom, the market value, the terminal scale and the terminal data (Guardian February 10, 2000). This has been the case in theory in the Nigerian public health care system. But the unfortunate thing is that public hospitals which are supposed to provide curative, preventive and rehabilitative health services affordable to the general public are all but mere consulting centre. Most of these hospitals present a picture of backwardness, decay and dilapidation. Most of them are made up of over-congested unhygienic and crumbling old structures which were built during the colonial period. The 'OS' (out of stock) syndrome is a very common phenomenon. Most of the facilities in these public hospitals are in various stages of decay and neglect. The above situations has led to serious brain drain-a situation where professionals in the health sector go abroad to find greener pasture or more so a worse brain drain where professionals are not practicing instead, you find a medical doctor going into trading, selling motor-spare parts and other nonmedical commodities. This is the real brain drain because much is invested in the training of these professionals. It is worthy to note that the most frustrating thing for a professional is not only that he is not able to practice his profession the way he wants as a result of lack of the necessary equipment that he needs but his pay package has to be something that is 'fat' enough to enable him meet his financial obligations (Duru \& Nwagbos 2007, Zaggi 2013).

Thus, this paper will examine the effect of the economic crisis on the health sector and try to proffer ways whereby the public hospitals and private ones can operate side by side.

\section{The Nigerian Economic Crisis}

The early signs of the current crisis of the Nigeria economy appeared in 1976 when the services sector of the country's payment began to record a persistent deficit. Although the trade balance was still in surplus, this was not to last because by 1978, it also began to run a deficit. The economic crisis has been caused by the 
inner, contradiction of the pattern of capital accumulation on which economic activities in the country have rested. The contradiction between social production and consumption has always been a serious one for Nigeria, expressing itself in the problem of matching social surplus with investments for expanded reproduction. It is quite obvious that most of the social surplus had not been utilized in the economy; the various arms of capital have transferred large amount of such surpluses overseas by way of dividend corrupt import practices that are a cover for capital transfers, and the actual importation of manufactured commodities food, raw materials and capital inputs (Olukoshi, 1991). The National Economic Councils State of the Economy Report confirmed this by stating that for every N1 given to Nigeria and transnational companies $68 \mathrm{k}$ founds its way outside the economy, furthermore, local and transnational producers were denied the opportunities of stable production through partisan allocations of import licenses (Abubakar, 1983).

Despite the huge amount of profit generated in all sectors of the Nigerian economy such as in oil, banking, manufacturing and the state, the level of development remains very low as a substantial part of the surplus is spent either in consumption or in overseas investments. This economic crisis did not spare the health sector of the economy. The federal government is biased in the allocation of fund to the health sector. Not only that very often this money is not released and when it is partly released, it is either misappropriated or mismanaged, consequently, most hospitals lack equipment and drugs to treat their patients (Guardian, February 5, 2000). Furthermore, for various reasons ranging from poor salary ill equipment, asphyxiating government policies on health and the general economic quagmire that have shrouded the country reasonable number of health workers especially physicians are steadily emigrating from the country in search of greener pasture abroad (Anele, 1998).

Those that could not leave open their own private clinics and very often are more loyal to their private practices than government work. Others leave medical profession to other businesses in order to make ends meet.

\section{Economic Crisis and Health Delivery System}

Third world countries in general have weak economics, which are dependent on the economics of the affluent and industrialized nations, with the result that whenever there is a trauma of world economy, the third world countries particularly, the developing nations are adversely affected. Such global economic traumas imply that the various governments would make adjustments in their economy in order to keep the individual economy going. Whereas some developing countries would resort to borrowing at stringent conditions from the affluent west, others will resort to internal rearrangements and adjustments of economic measures in order to keep government business afloat. Nigeria resorts to the later.

Although Nigeria exports oil in large quantity, the global economic trauma did not spare her. This is because of a prevalent oil glut preceding the world wide economic crisis. As a result, oil prices were slashed below inestimable values and mandatory cut in production quota. As a consequence, revenue accruing to the government can no longer meet its legitimate obligations such as provision of employment to the young school leavers' efficient health care delivery services etc.

In order to counter the severe effects of the global economic crisis, Nigeria introduced series of rearrangement and adjustment programmes, which also have their attendant hardships. This internal rearrangement of the economy resulted in mass retrenchment of workers, factories 
produced at under-installation capacity and in most cases some are shut down because of lack of raw materials, government services are under founded, and key areas like the health sector are not spared. Hospitals now become mere consulting clinics as they lack drugs and dressing (Igwe, 1992).

The masses on the other hand cannot afford the cost of decent healthcare services. This is because pa-capital income is very low. A greater percentage of the income goes into feeding. As a result, they patronize the quacks that are readily available and charge less. As Ekwonwa (1999) recorded, they are in every corner in their salon selling drugs, practicing medicine, giving injections behind curtains and running their own hospitals and clinics. Others on the other hand go for alternative sources of therapy. According to Alubo (1996) alternative therapeutic options can be broadly categorized into traditional, spiritual and folk medicine.

\section{The Private Health Care Delivery System in Port Harcourt}

Port Harcourt is the capital of Rivers State in Nigeria and one of the most rapidly developing urban industrial area. This growth has not only been due to its expanding functions as an economic and commercial center, but also an administrative and industrial center which has attracted a great number of people and activities, chief of which is the discovery and exploitation of crude oil in large quantities (Akpogomeh, 2005). This has been followed by the influx of numerous oil companies into the city with its socio-economic consequences one of which is the high rate of migration of persons from all over the country and even outside. Presently, Port Harcourt has a very high level of over population and unemployment. As at 1975, it was recorded that Port Harcourt had seven health care institutions, of which only three had provision for in-patients, (Mezie-Okoye,
1999). There is therefore a gross population. Port Harcourt being the center of oil industry in the country has the attendant specific environmental problems. The vast quantity of oil spillage waste and bye-products pollute the air poison its water and rivers, the increasing number of vehicles on the roads help in polluting the atmosphere. Also, the city finds it extremely difficult to manage its waste. There are heaps of refuse dumps here and there. All these constitute health hazards. Healthy problems caused by accidents also abound in Port Harcourt. There are accidents on the road on daily basis; people are always in a hurry to go to work. Most of them find themselves in the hospitals at the end of the day. There are also accidents in the industries and factories (i.e. machine accidents). All these people need medical attention. Deficiency and nutritional health problems are also very common in Port Harcourt. This is as a result of inflation unemployment and unequal distribution of income. These create a big gap between the rich and the poor. The poor suffer from mal-nutritional disease and skin diseases.

Over population also have its own health problems. When the population of an area is very high, overcrowding will result. In Port Harcourt, many people are crowded in small rooms especially in places like Diobu. People in this area suffer from skin diseases and other heat disorder like heat stroke and heat exhaustion. Port Harcourt city needs both curative and preventive medical services. However, the increase in charge for both in and out patients in hospitals means that a growing number of people are unable to afford medical treatment. In every case, the women and children suffer first and most (Ekpenyong, 1992). Hence, they go for alternative means of treatment because they charge less and also are accessible.

On the other hand, the multinational companies in the state need decent health care delivery services for their staff especially the senior staff and expatriates. This has led to 
most professionals putting up their own private hospital. These hospitals are highly equipped to meet the standard which these companies require. The issue of 'out-of-stock' in drugs is not applicable to these hospitals, examples of these hospitals are prime medical consultants, owned by a gynaecologist working at the University of Port Harcourt Teaching Hospital (UPTH), Divine Grace Clinic owned by a gynaecologist working with Military Hospital in Port Harcourt and Odadiki Eye Centre to mention but a few.

Similarly, quacks have also opened their own clinics. A quack is anybody who makes exaggerated claim to cure all kinds of diseases, generally for financial gains (Kassy, 1965). According to Folawiyi (1988) cited in Ekwonwa (1999) they reduce medical standard, because they charge low fee. The illiterates, the poor and uninformed members of the public rush to them for treatment leaving qualified doctors with fewer patients to treat. It is also worthy to note that it is not only illiterates or school dropout that engage in medical quackery. A layman who opens up a drug store and in it, acts as a doctor, radiographer or a dentist is a quack (Mathias 2007).

\section{Origin and Problems of Private Hospitals}

In Nigeria entrepreneurship in medicine may be traced to the slave trade period, during which medical doctors participated in medical screening and selection slaves. Doctors were also aboard slave ships to minimize losses in the long transatlantic passage to the new world as an act of the British parliament made it obligatory "for all ships carrying slaves to have on board a licensed surgeon..." (Berman, 1982). After the abolition of slavery, private medical care existed in some corporation as well as in the few proprietary hospitals, clinics and maternity homes mostly in the urban centers unlike the medical missionaries whose activities were encouraged and subsidized by the state. Private medical care has been generally suppressed by both the Nigerian colonial and post colonial governments. They used both political and economic powers to undercut them in several ways. These include the reduction of charges in public hospitals - obviously to render them unprofitable, only medical certification from public hospitals were accepted for sick leave and related sick role benefits, many reasons have been adduced for these "persecutions" primary among which are exploitation and quackery. "Doctors" on private practice were for instance accused of exploiting the popularity of injection for material gain.

Finally, the Federal Government Private Practice Decree No. 5 of 1978 stipulated a mandatory 5 years post graduation experience as a prerequisite for entering private practice. All these were to discourage the establishment of private clinics (Alubo, 1996).

Despite the above difficulties, the private medical enterprise has continued to grow. The economic crisis in general and the crisis in public medical facilities in particular have turned the tide in favour of private medical enterprise. This increasing dominance of private medical care in Nigeria emanates from two interrelated factors. First the private sector in general in perceived to be more efficient and effective. Secondly, the public medical system is in acute crisis without drugs, equipment and basic essentials (Mathias 2007).

These growing shortages are in addition to a general lack of trust in public hospital and institutions in general. Thus, in spite of free medical care and education which were widely available in public institutions, there seems to be general preference for privately owned facilities which charge fees. Also, the condescending and non-challant attitude in the public sector are either completely absent or less pronounced in the private sector. Therefore, private medicine has 
now come to constitute an efficient alternative to the public system. Consequently, private health care delivery is no longer just medicine for the rich as people thought it to be, even as ability to pay continues to be a crucial determinant of access. Indeed for many Nigerians, private health care delivery is now the only source of western biomedicine. Furthermore, those who first attend the public system are routinely forced by frustration to end up in the private system (Ajala,1986, Igun,1989).

This growing importance of private health care delivery is not primarily due to the increase in the patients served. Rather its importance lies in the fact that it constitutes an alternative to the crisis-ridden [including crisis of confidence] public sector, although that later very often has the larger number of facilities and provides wider coverage. Private medical services are therefore an important component in the overall health care delivery system in the contemporary Nigeria.

\section{Conclusion and Recommendations}

From the discussion above, we discover that the health sector has been grossly affected by the economic crisis in Nigeria. This could be seen in budget allocation to the sector, very often when the money is released. It is either not properly implemented or mismanaged. Hence most government hospitals are not functional at all while others function as consulting clines without health personnel. This had made the people who can afford treatment in developed nations outside the country to go for it while the masses remain tied to the local derelict hospitals or go for alternative sources of therapy (Newswatch, December 10, 1996). Furthermore, the Federal Government is biased in the sitting of government hospitals and clinics. Most of these facilities are located in the cities leaving the rural areas with little or none. On the side of the health personnel, their salaries are lower than what their colleagues earn in most developed nations. Most of them cannot feed their families adequately or train their children in good schools. Theses have led to serious brain drain, a situation where professionals in the health sector go abroad for greener pasture or more so, a worse brain drain, where professionals are not practicing enough. It is common to find a medical doctor going into trading, selling motor spare-parts and other non-medical commodities. It is this above situation that has led to the sprouting of private hospitals. Medical doctors who left the public hospitals open their own private clinics while others practice privately even though they are staff of the public hospitals. It is also worthy of note that most of these private hospitals in Rivers State are located in the city of Port Harcourt were the need for decent and well equipped hospitals is very high because of the presence of oil companies and other commercial and industrial companies. Also considering the high degree of health hazards in Port Harcourt, there is high need for private medical health care to compliment the public health care system. Hence, private health care delivery is no longer just medicine for the rich, even as ability to pay continues to be a crucial determinant of access. Indeed for many Nigerians especially those in Port Harcourt City, private medicine is now the only source of Western medicine. This is because those who first attend the public hospitals are forced by inadequate attention to end up in the private system.

This is a clear indication that the growing importance of private medical care is not only due to increasing number of patients but to the fact that it constitutes an alternative to the crisis including crisis of confidence in the public sector.

\section{Recommendations}

Based on the foregoing, the following suggestions were made: 
1. One of the ways to improve the services in the public hospital is for the doctors to be well remunerated. Most of them leave the public sector to open sub-standard hospitals or even leave the country out of frustration. The Guardian of $26^{\text {th }}$ February, 1984 reported that an estimated 1000 highly skilled Nigerian doctors have migrated in the past two years. The University of Lagos Teaching Hospital alone lost 425 highly skilled personnel in three years. Most of them are drawn from obstetrics and gynecology, surgery and radiology and they go to Saudi Arabia and other Gulf States. The Guardian of January 1989 also reported that a onetime state commissioner of Health of one of the states in Nigeria was spotted in a queue of job in Saudi Arabian embassy. If doctors in the public sector are well remunerated, these specialists will neither leave the country nor have any reason to go out to engage in private practice. More so they will put in their best.

2. Oil companies in Rivers State should help in purchasing drugs and equipment for the public hospital in view of the fact that they are the major contributors to the health hazards in Port Harcourt. The primary causes of health problems in Port Harcourt are environmental pollution, over population and inflation.

3. It is worth nothing that private medicine makes a great contribution to governments professed commitment of health-for-all especially in the rural areas where public medical services are virtually non-existent and in the context of the present economic crisis, which has precipitated a crisis in the public health sector. It is however, one thing for services to be available and another for such services to be accessible and genuine. There are often barriers to accessibility prominent among them is the high cost involved. Often they change fees that are 300 to 500 percent higher than the going rate in the public sector. Their reasons for this have always been the high cost of importing drugs and equipment. The federal government should reduce the import duties on drugs so that the private hospitals can import their drugs and equipment.

4. Private practitioners should also be encouraged to run mobile clinics. This is an area which private health care delivery has not really covered considering the high rate of accident and other health hazards in Port Harcourt, there is need for more mobile clinics.

5. The sole authority on the insurance of patient medicine license should be given to the Pharmacist Council of Nigeria (PCN). This is to prevent medicine dealers from selling fake drugs to the public. The body that is responsible for regulating medical practice in the country, that is the Nigeria Medical and Dental Council (NMDC) should properly check any hospital before it is accredited. Secondly, they should encourage those hospitals that are below standard to upgrade their services while those who cannot upgrade their standard should be forced to close down.

\section{References}

1. Abubakar, A. (1983). The Current State of the Nigerian Economy and its Challenges to Policy Markets CBN Economic and Financial Review. 23 September, pp. 12-26.

2. Achebe, C. (1983). The Trouble with Nigeria. England: Hienemann

3. Ajala, L. (1986). Medical Practice in Nigeria. Lagos: University Press.

4. Akpogomeh, O. S. (2005). A Guide to Port Harcourt Metropolis and its Environs. Ibadan: Kraft Book Ltd.

5. Alubo, O. (1996). Medical Professionalism and State Power in Nigeria. Jos: Ehindaro Press Ltd. 
6. Barman, F.B.S. (1982). Redressing Nigerian Financial System: A Study of Nigeria at the Financial Cross Road in Applied Financial Intermediation. Ibadan: University Press.

7. Duru, E.J. \& Nwagbos, C.I. (2007). The problems and prospects of public health care developmentin Nigeria's local government system in Global Journal of Social Sciences. Vol 6 (1) $51-56$.

8. Ekpenyong, S. (1992). The City in Africa. Lagos: African Heritage of Research Publications.

9. Ekwonwa, M. O. (1990) Medical Quackery its impact on Health Care Delivery Services in Nigeria. A case study of Owerri Municipality .PhD (Sociology) Thesis, University of Port

Harcourt (Unpublished).

10. Guardian Newspaper (1984) February 26.

11. Guardian Newspaper (1989) January 12.

12. Guardian Newspaper (2000) February 10.

13. Igun, O. (1989) The Nigeria Medical Practitioners. Ibadan :University Press.

14. Igwe, S. A. (1992) The Effects of Structural Adjustment Programmes (SAP) on the Attainment of Health for all by the year 2000, in Nigerian Structural Adjustment Programme a Multilateral Analysis. Ed by Aham Anyanwu. Enugu: Abic Books and Equipment Ltd.

15. Kassay, C. (1965) Health Care and Society. Cambridge: Cambridge University Press.

16. Mathias, B. A. (2007) Preventive Medicine in Nigeria: A study of Port Harcourt and Owerri in Nnamdi Azikiwe University Journal of Sociology. Vol 4 (1).

17. Mezie-Okoye, C.C. (199) Population and Economic Development in Nigeria: A study of Transportation Services in Port Harcourt.

18. Newswatch Magazine (1996) December 10.

19. Olukoshi, A, (1991) Crisis and Adjustment in the Nigerian Economic.Ibaban: JAD Publishers Ltd.

20. Osunkoya, B. O. (1984) Immuno-biological Research of major Diseases in PreIndustrialized Tropical Cities in Strategy for Medical Research in Nigeria ed. By Enwonwu Onyezilli and Ejezue, Ibadan: University Press.

21. Tamuno, S. O. (1998) Economic Crisis in Nigeria in The Nigerian Environment and Social Economic Development (ed.) by Iworrimie Jaja, Port Harcourt, SIJ Publishers.

22. Zaggi, H. (2013) Faces of Nigeria Health Sector in Daily independent, October 10. 


\title{
Экономический кризис и система здравоохранения: \\ опыт частного здравоохранения \\ в г. Порт-Харкорте, Нигерия
}

\author{
Бентина Алавари Матиас ${ }^{a}$, Атанасиус Н. Амасиату ${ }^{0}$ \\ ${ }^{a}$ Университет Намди Азикивеб Авка \\ Нигерия \\ ${ }^{6}$ Университет Порта Харкорта \\ Чоба, Нигерия
}

В статье рассматривается текущий экономический кризис в Нигерии и его влияние на частный медицинский бизнес на примере г. Порт-Харкорта. Также представлен краткий обзор экономического кризиса в Нигерии по отношению к системе здравоохранения. Рассматриваются виды экономической деятельности изучаемой сферы с иелью адекватного восприятия исследуемого случая и понимания сочиальныхх, экономических и политических условий, оказавших значительное влияние на частную медицинскую практику в г. ПортХаркорте. В статье анализируются истоки частного здравоохранения в Нигерии в иелом и в г. Порт-Харкорте в частности, а также его влияние. Авторами предложены варианть улучшения системы здравоохранения.

Ключевые слова: экономический кризис, здравоохранение, медицинский бизнес, частная практика.

Научная специальность: 08.00.00 - экономические науки. 